\title{
Leadership styles of futsal coaches from athletes' perceptions
}

\section{Selcuk BUGDAYCI ${ }^{1}$, Ozlem ZENGIN ${ }^{1}$, Ugur ABAKAY², Hayri DEMIR ${ }^{1}$}

\author{
${ }^{1}$ Faculty of Sport Sciences, Selcuk University, Konya, Turkey. \\ 2 School of Physical Education and Sport, Gaziantep University, Gaziantep, Turkey. \\ Correspondence address to S. Bugdayci, e-mail; sbugdayci@gmail.com
}

\begin{abstract}
The present is a descriptive research, the purpose of which is defining leadership styles of futsal coaches, who serve as faculty members at higher education institutions in Turkey, from athletes' perceptions. The data were collected from 337 athletes (147 female, 188 male), who participated in UNILIG futsal competitions organized by the Ministry of Youth and Sports. "Leadership Scale for Sports: Athlete's Perceptions of Coach's Behaviour" adapted to Turkish by Güngörmüş et al. was utilized as the data collection tool. According to the findings of the present research conducted to define the leadership styles of futsal coaches, futsal players' perceptions of their coaches' educative supportive and explanatory awarding behaviours are negative, perceptions of democratic and autocratic behaviours are positive, female players' perceptions of educative teaching, democratic behaviours and explanatory-awarding behaviours are more positive than male players, and perceptions of democratic behaviours of athletes, who have been training with the same coach for 5 years are more positive than the ones, who have been training with the same coach for 3 years or less.
\end{abstract}

Keywords: Coach, futsal, leadership.

\section{INTRODUCTION}

Many leaders with various characteristics in many fields have shown up so far, and these leaders were followed great societies. The concept of leadership appeared with people living together, and has reached today in different approaches and styles but with a constant effect (11).

People living in societies have always needed an individual to maintain the order within their societies and their relationships with other societies in a certain order. These individuals have become leaders, who have stood out with their knowledge and skills, and distinctive characteristics, and led the societies (6).

Leadership exists in every area of life, and it is important for the continuity of the tasks that must be done. Leadership includes the activities of planning and organizing the human and material resources, establishing and maintaining coordination between those, and inspecting the obtained outcomes in order to achieve the tasks of a society. A perfect leadership is only possible with good management and organization skills (8).
Since leadership is the art or skill of ruling, tasking and activating humans, it varies by the socio-economic structures, cultures, organizational styles and activity fields of the societies. Additionally, one of the most important topics of inservice trainings offered for personal development and establishing an organizational culture is leadership (4).

As a result, the institutions and academics offering this kind of trainings are forced to produce new concepts in leadership, and forming new syntheses of these concepts by the commercial concerns, and accordingly the area of leadership faces many theories, hypotheses, concepts and variations of these.

Leadership behaviour is a concept related to the leaders' attitudes towards their relationships with their followers or the members of the groups they are leading. Different behaviours exhibited by the leaders produce leadership styles. Therefore, the name of the leadership style is defines by the types of behaviours leaders display while managing the activities of the group they are leading (4). In other words, the type of the leadership exhibited the 
leader is one of the criteria distinguishing one group from another. Leadership style refers to the behaviour patterns formed by the interactions of the tasking behaviours presented to attain the objectives and the relationships between the leaders and the members of their groups (18).

There are many different opinions about defining leadership styles. However, the basis of all these opinions is about the selection of correct leadership style for attaining the objectives of the organization. Correct leadership style is very important for the motivation of the group members. According to the related literature, there are mainly three leadership styles; autocratic, democratic and free-rein (1).

Authoritative leaders exclude group members. They undertake the control and management of all steps of the organization themselves. They are highhanded with group members and want their instructions carried directly (5). They are not objective in awarding and punishing practices, and expect unconditional obedience and loyalty from group members $(10,13,15)$.

Democratic leaders include group members' ideas and opinions in decision making processes and encourage them to take part in planning, decision-making and organization activities (3).This type of leaders are in close relationship with their groups. Defining the objectives and the methods to attain these are done with the common decision of group members and the leader serves the role of a guide or assistant (10). Unlike authoritative leaders, democratic leaders make use of the dynamics within the groups while they supervise and even the leader is separated from the group, developed relationships and sense of responsibility within the group prevent a distinct decrease in the activity strength of the group (2).

Free-rein leaders are the individuals who least need the authority to manage. They leave their group members to their own resources and let them make their own plans and programs within the available resources (5). Group members are provided with full liberty in managerial and organizational tasks and ideas and wishes of group members are always important (7). Group members set their objectives on their own, and make their own decisions (12).

Developments in leadership in general terms also apply in the field of sports. Taken that sport clubs are organizational structures, coaches of the sport teams of these organizations are required to serve the role of the leader. In the field of sports, where contingency and constant developments and changes occur, coaches as the leaders should serve their functions in accordance with these conditions (1).

In light of this information, the purpose of the present research is defining the leadership styles of coaches of futsal, which is an indoor sport, which is becoming more and more popular every day in the world and Turkey, from the perspectives of athletes, and whether these vary by athletes' gender, age, experience in sport, and the length of time for working with the same coach variables.

\section{MATERIALS \& METHODS}

The present research is a descriptive study, the purpose of which is defining the leadership styles of futsal coaches, who work as faculty members for higher education institutions in Turkey, from athletes' perceptions.

\section{Research Group}

Research group consist of 337 (149 female, 188 male) futsal players, who participated in 2015-2016 Academic Year UNILIG Futsal Competition, organized by the Ministry of Youth and Sport and Turkish Federation of University Sports. Demographic data and their distributions are presented in Table 1.

Table1. Demographic data for participants $(n=337)$.

\begin{tabular}{llcc}
\hline & & $\mathrm{n}$ & $\%$ \\
\hline Gender & Female & 149 & 44.2 \\
Age & Male & 188 & 55.8 \\
& 18-21 years old & 154 & 45.7 \\
& 22-25 years old & 159 & 47.2 \\
Experience in Sports & 26+ years old & 24 & 7.1 \\
& 1-5 years & 132 & 39.2 \\
& 6-10 years & 125 & 37.1 \\
The length of time for & 11 + years & 80 & 23.7 \\
working with the & 1 year & 135 & 40.1 \\
present coach & 2 years & 77 & 22.8 \\
& 3 years & 68 & 20.2 \\
& 4 years & 51 & 15.1 \\
& 5,00 years & 6 & 1.8 \\
\hline
\end{tabular}

Table1 shows demographic data for the participants. Additionally, most of the participants are 25 years old or younger and male. 


\section{Data Collection Tool}

“Leadership Scale for Sports: Athlete's Perceptions of Coach's Behaviour" developed by Chelladurai and Saleh (1980) and adapted to Turkish by Güngörmüş, Gürbüz and Yenel (8) was utilized as the data collection tool for the present research. The original form of the scale consists of 40 items, but factor analysis conducted for the Turkish adaptation showed that factor loads of 6 items were below .40. Therefore, these 6 items were excluded from the scale and the final form included 34 items under 4 dimensions. These are; Educative Supportive Behaviour including 12 items, Democratic Behaviour including 10 items, Explanatory Awarding Behaviour including 7 items and Autocratic Behaviour including 5 items. Cronbach Alpha values of dimensions of dimensions were found to vary between .71-87 and internal consistency coefficient for the scale was calculated as .84 .

\section{Data analysis}

Data collected for the present research were analysed with SPSS 22.0 statistical program. Normality of the distribution of data was tested with Kolmogorov-Smirnov normality test. KurtosisSkewness values were studied for data sets, which didn't distribute normally, and since these values were within $+2 /-2$ range, they were found to distribute normally. Group of two were analysed with Independent Samples $T$ Test and One Way ANOVA test was used for groups of more than two.

\section{RESULTS}

Table 2 presents the distribution of the average scores for dimensions of the scale. Accordingly, score averages were 1.95 for educative supportive behaviour, 2.33 for democratic behaviour, 1.94 for explanatory awarding behaviour and 2.69 for autocratic behaviour.
Table 3 presents the variation in the perceptions of leadership styles by gender. Accordingly, there was a significant difference in educative supportive behaviour, democratic behaviour and explanatory awarding behaviour dimensions in favour of female participants $(p<0.05)$. There was not a statistically significant difference between female and male participants in terms of autocratic behaviour dimension $(\mathrm{p}>0.05)$.

Table 2. Distribution of perceptions of participants by scale dimensions.

\begin{tabular}{lccc}
\hline & $\mathrm{N}$ & Mean & SD \\
\hline Educative Supportive Behaviour & 337 & 1.95 & .64 \\
Democratic Behaviour & 337 & 2.33 & .78 \\
Explanatory Awarding Behaviour & 337 & 1.94 & .65 \\
Autocratic Behaviour & 337 & 2.69 & .82 \\
\hline
\end{tabular}

Table 4 presents the variation in the perceptions of leadership styles by age variable. Accordingly, there were not any significant variations in the perceptions of leadership styles of coaches by age $(\mathrm{p}>0.05)$.

Table 5 presents the variation in the perceptions of leadership styles by the length of experience in sport variable. Accordingly, there were not any significant variations in the perceptions of leadership styles of coaches by experience in sport $(\mathrm{p}>0.05)$.

Table 6 presents the variation in the perceptions of leadership styles by the length of time for training with the same coach. Accordingly, there were not any significant variations in the perceptions of leadership styles of coaches by the length of time for training with the same coaching three of the dimensions $(p>0.05)$, while there was a significant difference in democratic behaviour dimension in favor of athletes, who have been training with the same coach for 5 years $(p<0.05)$.

Table 3. Variation in coaches' leadership styles perceptions by gender.

\begin{tabular}{llccccc}
\hline & Gender & $\mathrm{N}$ & Mean & $\mathrm{SD}$ & $\mathrm{t}$ & $\mathrm{p}$ \\
\hline Educative Supportive Behaviour & Female & 149 & 2.05 & .67 & 2.528 & .012 \\
& Male & 188 & 1.87 & .61 & & \\
Democratic Behaviour & Female & 149 & 2.44 & .87 & 2.436 & .015 \\
& Male & 188 & 2.23 & .69 & & \\
Explanatory Awarding Behaviour & Female & 149 & 2.05 & .67 & 2.575 & .010 \\
& Male & 188 & 1.86 & .62 & & \\
Autocratic Behaviour & Female & 149 & 2.66 & .78 & \multirow{2}{*}{.519} & .604 \\
& Male & 188 & 2.71 & .85 & & \\
\hline
\end{tabular}


Table 4. Variation in coaches' leadership styles perceptions by age.

\begin{tabular}{llccccc}
\hline & & SS & SD & MS & F & p \\
\hline Educative Supportive Behaviour & Inter-groups & .225 & 2 & .113 & .273 & .761 \\
& In-group & 137.810 & 334 & .413 & & \\
& Total & 138.036 & 336 & & & \\
& Inter-groups & .903 & 2 & .451 & .738 & .479 \\
& In-group & 204.263 & 334 & .612 & & \\
Eemocratic Behaviour & Total & 205.166 & 336 & & & \\
& Inter-groups & .473 & 2 & .236 & .564 & .569 \\
& In-group & 139.982 & 334 & .419 & & \\
Autocratic Behaviour & Total & 140.455 & 336 & & & \\
& Inter-groups & .886 & 2 & .443 & .666 & \\
& In-group & 222.283 & 334 & .666 & & \\
& Total & 223.169 & 336 & & & \\
\hline
\end{tabular}

Table 5. Variation in coaches' leadership styles perceptions by experience in sports.

\begin{tabular}{llccccc}
\hline & & SS & SD & MS & F & $p$ \\
\hline Educative Supportive Behaviour & Inter-groups & 1.636 & 2 & .818 & 2.003 & .136 \\
& In-group & 136.399 & 334 & .408 & & \\
& Total & 138.036 & 336 & & & \\
& Inter-groups & .499 & 2 & .250 & .407 & .666 \\
& In-group & 204.666 & 334 & .613 & & \\
& Total & 205.166 & 336 & & & \\
Eemocratic Behaviour & Inter-groups & 1.441 & 2 & .721 & 1.731 & .179 \\
& In-group & 139.014 & 334 & .416 & & \\
Autocratic Behaviour & Total & 140.455 & 336 & & & .207 \\
& Inter-groups & 2.097 & 2 & 1.048 & 1.584 & \\
& In-group & 221.073 & 334 & .662 & & \\
& Total & 223.169 & 336 & & & \\
\hline
\end{tabular}

Table 6. Variation in coaches' leadership styles perceptions by the length of time for training with the same coach.

\begin{tabular}{|c|c|c|c|c|c|c|c|}
\hline & & SS & SD & MS & $\mathrm{F}$ & $\mathrm{p}$ & $\begin{array}{l}\text { Significant } \\
\text { difference }\end{array}$ \\
\hline \multirow[t]{3}{*}{ Educative Supportive Behaviour } & Inter-groups & 2.664 & 4 & .666 & 1.633 & .165 & \\
\hline & In-group & 135.372 & 332 & .408 & & & \\
\hline & Total & 138.036 & 336 & & & & \\
\hline \multirow[t]{3}{*}{ Democratic Behaviour } & Inter-groups & 5.948 & 4 & 1.487 & 2.478 & .044 & $5-1$ \\
\hline & In-group & 199.218 & 332 & .600 & & & $5-2$ \\
\hline & Total & 205.166 & 336 & & & & $5-3$ \\
\hline \multirow[t]{3}{*}{ Explanatory Awarding Behaviour } & Inter-groups & .920 & 4 & .230 & .547 & .701 & \\
\hline & In-group & 139.535 & 332 & .420 & & & \\
\hline & Total & 140.455 & 336 & & & & \\
\hline \multirow[t]{3}{*}{ Autocratic Behaviour } & Inter-groups & 2.612 & 4 & .653 & .983 & .417 & \\
\hline & In-group & 220.557 & 332 & .664 & & & \\
\hline & Total & 223.169 & 336 & & & & \\
\hline
\end{tabular}

\section{DISCUSSION}

This part of the present research includes the discussions of the obtained findings related to the leadership styles of futsal coaches from athletes' perspectives, and the variations in these by age, gender, experience in sport, and the length of time for training with the same coach variables.
According to the obtained findings, we can conclude that average scores for futsal players' perceptions of the educative-supportive and explanatory-awarding behaviours exhibited by their coaches are below average and so low; and average score for democratic behaviour is medium, while the 
score average for autocratic behaviour is above average.

Bensiz (1), who conducted a similar research on amateur football players, found that social support and educative behaviour scores were low, democratic behaviour score was medium and autocratic behaviour scores was above average. Toros and Duvan (2011) conducted a study on fencers and reported that democratic behaviour score was 2.66. The findings of these two studies are in agreement with the findings of the present research. However, according to the findings of many other studies conducted on football players and athletes of other sport branches, obtained scores were pretty high $(19 ; 15 ; 16 ; 14 ; 13 ; 17 ;)$ The reason for differences between the findings of the present study and other mentioned above can be the fact that futsal is a comparatively a new branch of sport in Turkey and therefore coaches exhibit different types of behaviours. As stated before, futsal is a recently developing branch of sport in Turkey, the federation hasn't organized a coaching training yet, there has been one Futsal Coaching certificate program offered by FIFA on 19-23 November 2016, and only 25 coaches training futsal teams for universities participated in this program.

According to the findings of the present research related to the variation by gender variable, female athletes' perceptions of their coaches' educative-supportive behaviour, democratic behaviour and explanatory-awarding behaviour are more positive than male athletes'. The reason for this finding may be the fact that most of futsal coaches are male and so they treat female athletes in a more sensitive manner.

According to the findings of the present research related to the variation by age and sport experience variables, there aren't any significant differences in athletes' perceptions of their coaches' leadership behaviours. This finding may be the result of the fact that the ages and sport experiences of the participants are similar.

One important factor in establishing communicative channels between the coaches and their athletes is the length of time they train together. For this reason, the present research studied whether the perceptions of athletes related to their coaches behaviours varied by the length of time they have been training together, and it was found that the athletes who had been training with the same coach had more positive scores than the athletes who had been training with the same coach for 3 years or less.

Consequently, the present research, which was conducted in order to define leadership styles of futsal coaches from athletes' perceptions, found that futsal players' perceptions of their coaches' educative-supportive and explanatory-awarding behaviours were negative, their perceptions of democratic and autocratic behaviours were positive, female players' perceptions of educative-supportive, democratic and explanatory-awarding behaviours were more positive than male players' perceptions, and perceptions of players, who had been training with the same coach for 5 years, related to their coaches democratic behaviours were more positive than the players', who had been training with the same coach for 3 years or less.

\section{REFERENCES}

1. Bensiz, A. Examination of the leadership characteristics of coaches according to the perceptions of the amateur football players. Master Thesis, Bartın University, Institute of Education Sciences, Bartın, Turkey.

2. Davis K. İşletmede İnsan Davranışı, Çev. Kemal Tosun, İstanbul Üniversitesi Yayınları, İstanbul, 1984.

3. Dinçer Ö, Fidan Y. İşletme Yönetimi, Beta Yayıncılık, İstanbul, 1996.

4. Erçetin Ş. Lider Sarmalında Vizyon, 2. Basım, Nobel Basımevi, Ankara, 2000.

5. Eren E. Yönetim ve Organizasyon, Beta Yayınları. İstanbul, 2003

6. Farland M, Lynne J, Larry E, Childress John R. 21st Century Leadership. The Leadership Press, Los Angeles, 1994

7. Genç N. Yönetim ve Organizasyon, Seçkin Yayınları, Ankara, 2005.

8. Güngörmüş H, Gürbüz B, Yenel İF. Evaluation of the psychometric properties of the "leadership scale for sports: Athlete's perception of coach's behaviour. Atatürk University Journal of Physical Education and Sport Sciences, 2008; 10(2):16-22.

9. Gürsoy A. Liderlikte duygusal zekâ (liderlik özellikleri ile duygusal zekâlı liderlere ulaşılması) Türk Silahlı Kuvvetlerinde Örnek Bir Uygulama, Celal Bayar Üniversitesi, Yüksek Lisans Tezi, Manisa, 2005.

10. Karaküçük S, Yetim A. Rekreasyon etkinliklerinde liderlik ve fonksiyonları. Gazi Üniversitesi, Beden Eğitimi ve Spor Bilimleri Dergisi, 1996;1(1): 64-76.

11. Kaya YK. Eğitim Yönetimi;Kuram ve Türkiye'deki Uygulama, 6.Baskı, Bilim yayınları, Ankara, 1999.

12. Mucuk İ. Modern İşletmecilik, Türkmen Kitap, İstanbul, 1996.

13. Sarı I, Soyer F, Yiğiter K. The relationship among sports coaches' perceived leadership behaviours, athletes' 
communication skills and satisfaction of the basic psychological needs. International Journal of Academic Research, 2012; 4(1):112-119.

14. Toros T, Duvan A. The relationship between perceived coaching behaviours, collective efficacy and goal oriantation among fencer players in Turkey, Nigde University Journal of Physical Education and Sport Sciences, 2011; 5(1), 33-41.

15. Türksoy A. Futbolda sporcu tatmini ile antrenörlerden beklenilen ve gerçekleşen liderlik davranışlarının tespiti. Marmara Üniversitesi Sağlık Bilimleri Enstitüsü, Doktora Tezi, İstanbul, 2008, 100-101.

16. Williams GP, An examination of the effect of coach leadership behaviors on the psychosocial development of division III college football players, 2010: ProQuest Dissertations and Theses.

17. Yalçın HB. Perceived leadership behavior in sports the interaction between individual differences and task characteristics. Life Science Journal, 2013; 10(2): 165-172.

18. Yetim AA, İmamoğlu A, Çimen Z. Accepted approaches of sport managers in human relations. Gazi Journal of Physical Education and Sport Sciences, 1998; 3(3): 61-70.

19. Yılmaz İ.Sporcu algıları çerçevesinde farklı spor branşlarındaki antrenörlerin liderlik davranış analizleri ve iletişim beceri düzeyleri. Doktora tezi, Gazi Üniversitesi, Sağlık Bilimleri Enstitüsü, 2008. 